\title{
The Demand for Literature in France, 1769-1789, and the Launching of a Digital Archive
}

\section{Citation}

Darnton, Robert. 2015. “The Demand for Literature in France, 1769-1789, and the Launching of a Digital Archive." The Journal of Modern History 87 (3) (September): 509-531. doi:10.1086/682412.

\section{Published Version}

doi:10.1086/682412

\section{Permanent link}

http://nrs.harvard.edu/urn-3:HUL.InstRepos:37143016

\section{Terms of Use}

This article was downloaded from Harvard University's DASH repository, and is made available under the terms and conditions applicable to Open Access Policy Articles, as set forth at http:// nrs.harvard.edu/urn-3:HUL.InstRepos:dash.current.terms-of-use\#OAP

\section{Share Your Story}

The Harvard community has made this article openly available.

Please share how this access benefits you. Submit a story.

\section{Accessibility}


The Demand for Literature in France, 1769-1789, and the Launching of a Website How did literature contribute to the collapse of the Ancien Régime in France? Alexis de Tocqueville raised this question in $1856 .{ }^{1}$ Daniel Mornet placed it at the heart of the polemics about the intellectual origins of the French Revolution in $1910^{2}$, and historians have argued about it ever since. One line of argument turns on the effort to calculate the production and diffusion of books. It may seem misplaced today, because quantitative history has given way to the study of political discourse and a broad range of cultural questions. ${ }^{3}$ No one, not even Mornet, would defend a linear view of causality, which leads from publishing to book sales, reading, collective attitudes, the formation of public opinion, and the overthrow of a political order. Yet the demand for literature remains relevant to the understanding of discourse and culture, including the cultural explosion of 1789. Exactly how it is relevant may be endlessly debated, but the debate will not get far without some solid data about the market for books on the eve of the Revolution. This essay is an attempt to provide that information.

It also has a second purpose: to introduce a website that will make available a great deal of information about literary demand and the way the book trade functioned under the Ancien Régime. Demand can be measured by 
compiling statistics from the orders of booksellers, but statistical evidence from eighteenth-century sources can easily be misinterpreted. When booksellers ordered books, they conformed to conditions, practices, attitudes, and folkways that no longer exist. In order to avoid anachronism and other errors of interpretation, it is important to study the texts of the booksellers' letters while tabulating data from them. The website--www://robertdarnton.org--includes hundreds of the letters as well as statistical tables and a great deal of other material. It is arranged in layers so that readers can drill down and search across bands of information, pursuing interests of their own as well as the central question of literary demand. Before setting out, however, they are likely to raise questions about methods and sources. A third purpose of this essay is to discuss those questions in a way that could be useful to historians in other fields who need to develop an effective research strategy.

Incomplete and unreliable sources make it devilishly difficult to compile statistics about the production and diffusion of books anywhere in Europe before the nineteenth century. In England, only a minority of newly published books were entered in the registry of the London Stationers' Company. In Germany, the 
catalogues of the book fairs of Leipzig and Frankfurt exclude a great deal of popular literature along with a large proportion of works from southern and Catholic regions. And in France, the official records are misleading in several ways. The registers of requests for book privileges exclude everything that was not submitted for formal approval by the censors - that is, if one includes pirated editions in the estimate, probably the majority of all new publications. Records of books submitted for other kinds of permissions - permissions tacites and permissions simples-do not indicate what books were actually published and how many copies were printed, to say nothing of sales. There are no records of works that were allowed to be sold by informal arrangements with the policeso-called simples tolérances and permissions de police. And the enormous production of books that were printed outside France and marketed inside the kingdom cannot be estimated. I would guess that it constituted more than half the books in circulation between 1769 and $1789 .{ }^{4}$

Why such a high proportion? The approbation of a censor and the conferral of a privilege did not merely certify that a book contained nothing that would offend religion, the state, morals, or the reputation of an important personage. They served as a royal stamp of approval for the quality of the bookits style and contents as well as its ideological correctness. True, censorship 
became less rigorous during the last years of the ancien régime. But it took money, time, and trouble to obtain even a permission tacite, which was given more freely but did not convey an exclusive right to sell a book (unlike privileges, which functioned as the precursors to modern copyrights) and yet required the approval of a censor. The Parisian booksellers guild (Communauté des libraires et des imprimeurs de Paris) dominated the publishing industry, having destroyed most competition from provincial publishers, especially in Lyon and Rouen, during a trade war in the seventeenth century. Backed by the state's office for the control of the book trade (Direction de la librairie), the members of the guild profited from the exclusive right to print and sell books in the capital and a virtual monopoly of access to privileges for new works. They reinforced their power by policing the trade in Paris - that is, by inspecting book stores, printing shops, and the shipments of books that arrived at the city gates-and they often developed networks of client booksellers in the provinces. The crown attempted to correct some of the disadvantages suffered by the provincial dealers in new regulations on August 30, 1777; but it never succeeded in restoring much competition. ${ }^{5}$

In the face of these constraints and costs, many authors and provincial publishers preferred to have their books produced outside France and to market them inside the kingdom while arranging for inspectors in the provinces to look 
the other way. Dozens of publishing houses sprang up like mushrooms around France's borders, extending from Amsterdam through the Austrian Netherlands and the Rhineland to Switzerland and Avignon, which then was papal territory. Foreign publishers of French books had done a brisk business during the sixteenth century in order to satisfy the demand for Protestant works. In the eighteenth century, they produced nearly all the works of the Enlightenment along with everything else that could not pass the censorship. But they made most of their money from piracy. The term may seem misleading, although it was widely used at the time, because publishers in Geneva or Amsterdam did not violate local laws by reprinting books that had originally appeared in Paris. No international copyright agreement existed. But when the foreign publishers sold their editions inside France, they aroused the fury of the owners of the original privileges, who were nearly always booksellers in the Parisian guild. (Authors could not sell books themselves before the reforms of 1777 and rarely did so afterward.)

The provincial booksellers, by contrast, were natural allies of the foreign publishers, primarily because of economic factors. They usually could procure pirated books at lower prices than the originals, which had to be produced according to quality standards set by royal regulations. Conditions varied, but paper, which represented half or more of production costs depending on the size 
of the pressrun, often was cheaper outside France. The pirate publishers also undercut the Parisian editions by eliminating what they called "typographical luxury" - for example, wide spacing, generous margins, illustrations, and the use of expensive fonts of type. They reprinted books that were selling well, according to reports from their Parisian agents and provincial retailers; and they did not have to advance capital to purchase the original manuscripts from the authors. True, they needed to have their books smuggled into France, but they could count on allies among the booksellers who inspected shipments in distribution centers like Rouen and Lyon. Despite occasional breakdowns, the illegal distribution system supplied relatively inexpensive books to a broad public everywhere in provincial France. This kind of publishing, based on pirated and uncensored editions, had developed into a major industry by 1750 , much to the chagrin of royal officials, who deplored the flight of capital to foreign manufacturers. It outdid the upscale, Paris-centered, and guild-based system in linking production to demand. ${ }^{6}$

How to measure demand? That is the problem I have addressed by compiling information from the papers of the Société typographique de Neuchâtel (STN), the only publishing house from this era whose archives have survived almost completely intact. The enormous collection of STN documents 
reveals literary demand in two ways: first, by letters with orders for books sent by booksellers in nearly all the important cities and towns of France from 1769 to 1789; second, from various account books, where the STN's clerks recorded the orders and the shipments sent in response to them. With the help of a series of research assistants over the last fifteen years, I have chosen a sample of the most important customers of the STN, transcribed their dossiers, compiled statistics from their orders, added transcriptions of dossiers from the middlemen of the book trade, mapped trade routes, furnished information about the social and economic conditions in each of the cities, and digitized all of the original manuscripts.

Rich as it is, the material comes almost entirely from one source, and therefore any user of the website is bound to question the representativeness of the STN archives. No comparable source exists. In an earlier study, The Forbidden Best-Sellers of Prerevolutionary France (W. W. Norton, New York, 1995) and its companion volume, The Corpus of Clandestine Literature in France, 1769-1789, I was able to calculate and map the demand for forbidden booksnot pirated works but books that were unambiguously illegal, as determined by contemporary criteria-and I could check my results against a few complementary sources, such as reports on police raids in book shops, 
confiscations in the Parisian customs, and special catalogues of forbidden books. In contrast, the statistics given in the website cover books of all kinds-that is, all the works that circulated in the French market during the twenty years before the Revolution. How could one publisher's trade represent such an enormous variety of literature?

As an index to the overall market, it can only be approximate; but the STN archives, which contain about 50,000 letters, are rich enough to provide an adequate sample of the demand for books as it was expressed in the correspondence of booksellers located nearly everywhere in France. In order to appreciate the importance of this evidence, it is necessary to understand two factors that characterized Swiss-French publishing in the eighteenth century: first, the way houses like the STN operated, both as publishers and as wholesalers; second, the way booksellers in France ordered books. Both illustrate crucial aspects of early-modern publishing that distinguish it from publishing today.

The STN rarely published original editions, unless it was commissioned to do so by authors who covered the costs. It reprinted-or "pirated," as the original publishers would put it-books that were already selling well. In choosing them, it studied the market carefully and followed advice that it received from 
the best informed booksellers in its vast network of clients. But it did not sell only the books that it produced in its own printing shop. When it printed an edition, usually at a run of about 1,000 copies, it commonly traded a large proportion100 or more copies - for an assortment of an equal number of books in the stock of one or more allied publishers. Exchanges were usually calculated according to the total number of sheets involved in the trade; and when the STN selected an assortment, it chose the books that it thought would sell best. In this way, it maximized the value and variety of its stock, and at the same time it minimized risk, because it could not be sure that an edition it printed would sell out or would sell rapidly enough to cover the investment of its capital. When a bookseller ordered a work that it did not have in stock, the STN often procured it by an ad hoc trade or a discount purchase with an allied publisher in Lausanne, Geneva, Bern, or Basel, who operated in the same manner. Publishing as practiced by the major Swiss houses was therefore inseparable from wholesaling, and cooperation among the publisher-wholesalers meant that they could draw on a large corpus of literature, a kind of invisible, floating stock, which was available to all of their allies.

The importance of exchanges in this publishing system has never been noted by historians, except in the case of Germany, where it functioned as the 
primary means of marketing books until the late eighteenth century. ${ }^{7}$ In Switzerland, it continued to be a vital force until the French Revolution, and it spilled over into Swiss relations with certain houses in Lyon, Avignon, and even the Low Countries, despite the transport costs. Of course, the Swiss publishers often competed, but they also created alliances, which reinforced the links created by the exchange trade. Sometimes they published books together, sharing costs and risks. Joint publications were especially effective in speculations on pirated editions, when it was crucial to beat other pirates to the market before the demand dried up. At various times the STN concluded formal treaties with the Société typographique de Lausanne and the Société typographique de Berne so that all three houses combined forces to pirate books systematically and on a large scale. ${ }^{8}$

The swapping and pirating arrangements meant that the STN built up a large and varied stock of books, but some were more important than others in the general pattern of its trade. It sold more copies of books that it had printed than it did of books that it procured by exchanges. In describing its business in its commercial correspondence, it distinguished between "livres de fonds" (its own editions) and "livres d'assortiment" (general stock), and it separated them in its account books, where each of its own editions had a separate account in contrast 
to the exchanged books, which were grouped together in a "compte d'échanges." In compiling statistics from the archives, it is important to keep this distinction in mind - that is, to avoid giving equal weight to books published by the STN and books acquired by exchanges. In order to avoid misleading comparisons, the titles of the STN editions are set off in the statistical tables of the website by colored fonts, and the lists of books most in demand are given in two forms: a list that includes both kinds of books and a list that excludes the STN editions. In each case, the statistical base is strong enough to support general conclusions, because the overall stock of the STN grew to be enormous by the mid-1770s. In 1773 it claimed, "There is no book of any importance that appears in France that we are not capable of supplying. ${ }^{\prime 9}$ Its catalogue of 1785 contained 700 titles, and an inventory of its warehouses in 1787 included 1,500 titles.

The broad range of the books supplied by the STN was in part a response to the way booksellers placed orders for them. Practices varied, of course, but close study of the STN's correspondence shows that the wholesale trade involved two distinct kinds of transactions: hit-or-miss orders from transitory customers and steady orders from regular customers. The STN sent catalogues and prospectuses to hundreds of dealers. Most of them, attracted by a particular title or curious to try out the services of a new supplier, ordered only a few works and never 
developed regular commercial relations. They drew the bulk of their stock from other wholesalers, who offered better conditions or quicker shipping or had won a retailer's good will by years of reliable service. While dealing with these transitory customers as occasions arose, the STN built up its own network of regular clients. Their correspondence reveals a common tendency in the ordinary flow of the STN's business: when placing orders, retailers were cautious. They often arranged sales in advance with their own customers before committing themselves to purchase books from a foreign supplier; and rather than scattering orders among many suppliers, they usually restricted their trade to a few reliable houses. They tended to wait until they had accumulated enough items to group them in a single order. But they did not speculate on large shipments of one work unless they detected an unusual surge of demand. Instead, they ordered small numbers of several different books and later sent in new orders for those that continued to sell. As the widow of Jean-Félix Charmet explained soon after his death when she took over their business in Besançon, "My husband's principle [in ordering] was to take many items and small numbers of each." ${ }^{10}$ Returns did not exist in the eighteenth-century book trade. (In very rare cases, such as the liquidation of stock after a bankruptcy, books might be sold "en commission," but those arrangements had no resemblance to the modern practice of returns.) 
Therefore, booksellers rarely ordered more than a dozen copies of a single title (by ordering a dozen they sometimes got a free thirteenth) and ordered enough titles to form a shipment large enough for them to take advantage of cheaper rates.

Books were shipped unbound in bundles of sheets packed into bales (binding was normally arranged by individual customers and sometimes by retail booksellers). Wagoners would not accept bales that weighed less than 50 pounds, and they often gave discounts for bulk shipments. Small shipments, sent in packages ( $\underline{\text { ballots }}$ as opposed to balles) weighing less than 50 pounds, had to go by coach at a much higher price. The distinction between the wagon (voiture) and the coach (carrosse) was crucial in the book trade, because books had relatively low intrinsic value in relation to shipping costs. Also, the recipient normally had to pay for them in cash upon delivery. The letters of booksellers read like an endless wail about the cost of shipping.

Booksellers sometimes played suppliers off against each other in order to extract the most favorable terms, but they also developed special relationships with particular publisher-wholesalers, who could be flexible about payments, give their orders priority, and offer occasional discounts. Instead of dispersing their 
business among many suppliers, therefore, they often concentrated it among a few whom they could trust. Trust ("confiance") was a key term in the longdistance book trade (and probably in early capitalism everywhere), owing to the need to avoid cheating. The tricks of the trade could be exploited endlessly by entrepreneurs who operated far away from the home territory of their victims. Some publishers announced that they were reprinting a book merely in order to see whether the demand was sufficient to justify an edition, while at the same time deterring a competitor from publishing it. And they often played favorites with their shipments so that some booksellers creamed off the demand before others in the same area received their copies. The publisher-wholesalers suffered more from abuses of confidence than the retailers, especially in the shadier branches of the trade. Once they had won the trust of the STN, marginal dealers like Malherbe of Loudun piled order upon order, until they drew most of their stock from Neuchâtel, always finding an excuse to avoid paying bills of exchange on the date of maturity ${ }^{11}$. On the other hand, some scrupulously honest retailers, such as Charmet of Besançon, also sent the bulk of their orders to the STN, because they preferred to draw large numbers of books from a single supplier whom they had known for many years and who had proved to be both reliable and flexible if difficulties arose. Either way, the accumulation of orders makes it 
possible to form a general idea of the business of a bookseller who traded regularly with the STN.

I emphasize this point, because it bears on a critical decision about the best method for compiling statistics. It would be possible to work through all the accounts of the STN (beautifully kept registers called "journaux," "brouillards," and "mains courants") and to record the sale of every book to every customer. I considered this strategy when I began to study the STN's accounts along with its correspondence in 1965. It raised the prospect of tracing the diffusion of French literature everywhere in Europe. But closer examination showed that the results would be misleading. Although the STN corresponded with hundreds of booksellers located everywhere from Moscow to Naples and Budapest to Dublin, most of its correspondents belonged to the class of transitory customers. They placed very few orders-often only one or two, "par essai," as they put it. A few titles in the STN's catalogue would catch their eye, and they would make a trial purchase in order to assess the quality of the editions, the cost of transportation, and the time it took for the books to reach them. The great majority did not renew their orders, because they found that they could get better terms or quicker service from another supplier, usually one closer to home or one more firmly connected by ties of trust. Therefore, the STN often sold only a few copies 
of a particular book in a large area or an entire country, and the small number of copies that it managed to sell cannot be taken to typify the diffusion of that book or the trade of the bookseller who bought it. The irregular, hit-and-miss quality of the sales records makes it misleading to lump all of the sales together in an attempt to generalize about the dissemination of literature. Also, unfortunately, the data is too thin for one to reach conclusions about the general character of large markets such as Spain, Portugal, Denmark, Sweden, England, and Germany.

Consider the example of a great best-seller, Voltaire's Candide. The STN's accounts make it possible to plot every copy sold by the STN on a map of Europe, but the statistics are so trivial as to make the map useless. ${ }^{12}$ Fourteen copies were sold to booksellers in Moscow and Saint Petersburg, and none at all were sold in Spain, Portugal, the Low Countries, Britain, and Scandinavia. Can one conclude that the demand for Candide was greater in Russia than in all those other countries and that it had ceased to exist it in most of Western Europe during the years 1769-1789? Certainly not, because booksellers in those countries drew supplies from other publishers and wholesalers. Gabriel Cramer, Voltaire's publisher in Geneva, did a large trade in the Iberian Peninsula and probably sold many copies of Candide there, but one cannot know for sure, because all that survives from his papers is his "Grand livre" or general account 
book, which mentions his customers but not the books they bought. ${ }^{13}$ Voltaire exerted great influence on the cultural life of Berlin, thanks in large part to his relations with Frederick II; yet the STN did not sell a single copy of Candide there. By 1769 , the book market in Berlin and all of Northern Germany had fallen under the dominance of Philipp Erasmus Reich, the publisher who transformed the German trade, ${ }^{14}$ but Reich never had any contact with the STN. In fact, it is very difficult to follow the STN's sales in Germany, because most of them took place in the book fairs of Leipzig and Frankfurt from which they went to unknown destinations. ${ }^{15}$ Moreover, the STN did not sell them at the fairs by itself but worked through middle men such as Johann Jacob Flick and C. A. Serini of Basel and Emmanuel Haller and the Société typographique de Berne. The diffusion of the books left no trace in the STN's accounts. What the accounts do reveal is an extensive trade, by sales as well as exchanges, between the STN and other Swiss houses, who then sold its books within their own commercial networks. The ultimate destination of those books, which represent at least a quarter of the STN's business, cannot be determined.

Many of the same problems apply to the study of the STN's sales in France, its largest market. It never did much business in Paris, where the booksellers' guild, reinforced by the police, did everything possible to eliminate competition 
from foreign publishers who specialized in pirated editions. Provincial dealers were attracted by the STN's relatively cheap prices, but they often made a trial order to test the quality of the STN's editions or the effectiveness of its supply lines, and never came back. A delay in the shipment or a large number of spoiled sheets (défets) was enough to dissuade them from establishing regular relations. Their names show up once or twice in the STN's account books and then disappear. To be sure, the STN gradually built up a network of its own, but the process was irregular and uneven, making it difficult to compare sales in one city with those in another. In fact, most of the STN's contacts with retailers did not lead to enough sales for one to sketch even a tentative profile of their trade. Only in exceptional cases, such as the sales of the quarto edition of the Encyclopédie, can one draw on the STN archives to follow the diffusion of a book geographically and sociologically. ${ }^{16}$ And one cannot trace a large proportion of the STN's sales beyond its dealings with the middlemen in Geneva, Lausanne, Bern, and Basel. I see no way around a disappointing conclusion: any attempt to compile statistics by indiscriminately counting every sale recorded by the STN is bound to be fatally flawed. One attempt to follow this procedure, an online work entitled The French Book Trade in Enlightenment Europe, 1769-1794, commits these and other errors. 
Although it contains some useful maps and bibliographical information, it does not succeed in studying diffusion. ${ }^{17}$

Instead of lumping all of the STN's transactions together, I have opted for a strategy of sampling, and I have combined qualitative with quantitative analysis. To gauge the extent to which the orders of a bookseller can be taken to represent his business, it is necessary to compile an adequate number of them and also to read the letters in which they appear. Only by careful study of the correspondence can one determine the context of the sales, the conditions that determined their limits, and the nature of the rapport between customer and supplier. Booksellers usually wrote terse, business-like letters; but after they developed "confiance," a trusted relationship with the STN, they often interspersed their orders with personal remarks and reflections on the trade. Far from restricting themselves to business, their commercial correspondence then opens up a fresh view of life in provincial France, because in some cases, one can follow a bookseller from the time he sets up shop, gets married, develops a family, takes sick, and dies. Letters from neighbors and other merchants complete the picture. For all their homeliness-in fact because of it-the letters make fascinating reading. Hundreds of them can be sampled on the website. If 
studied along with the statistics, one can get the feel of the book trade as it was embedded deep in the social order of the ancien régime.

Only a small minority of the thousands of dossiers in the STN archives offer such a rich view. I have selected eighteen of them and, with help from research assistants, have transcribed all of the booksellers' letters, identified the books they ordered, and tabulated the number of copies ordered for each title along with the number of orders and the dates of their occurrence. Each bookseller's business had its own character, but the eighteen case studies conform to a general pattern. They provide a reliable indication of the demand for books over a large area of provincial France: the Eastern provinces, down the Rhône Valley, across Provence and Languedoc, up the West Coast to the Loire, along the Loire Valley to Burgundy and back through the Franche-Comté to Neuchâtel.

That was the itinerary followed by Jean-François Favarger, a sales rep (commis voyageur) of the STN, during a five-month tour de France in 1778. In his diary and correspondence, which are available on the website, he reported on all the booksellers he met, and the STN's replies, in addition to its written instructions in the diary, guided him in his attempts to sell books, settle accounts, 
and assess the trade in every town along his route. The richness of this

documentation complements the correspondence of the booksellers themselves.

Therefore, it is possible to compare a horizontal view of the trade in 1778 with a

vertical perspective derived from letters that stretch from 1769 to 1789 . I studied

all the dossiers of all the STN's customers in the rest of France, but instead of

attempting to extend the statistical sampling beyond Favarger's itinerary, I

decided to concentrate on the parts of the archives where the documentation

was densest.

By combining quantitative analysis with a critical reading of the correspondence, it is possible to make inferences about the sale as well as the demand for books. In fact, the orders of the eighteen booksellers correspond quite closely to the books they actually received. In general, however, the STN often failed to supply some of the books ordered by a customer, either because it did not have them in stock or because it could not procure them from other publisher-wholesalers. In account books known as livres de commission, the STN's clerks recorded the orders on the left (verso) page of the register and the shipments on the right (recto) page. The disparities between the two facing pages demonstrate that the STN frequently failed to fill an entire order. But in the records of the eighteen booksellers, the match between the orders and the 
sales was usually very close, and therefore, the statistics can be taken as a rough measure of the diffusion of books as well as a more accurate picture of the demand for them.

This argument may be convincing as far as it goes, but does it go far enough to support sound conclusions? In advancing it, I am aware that I want my statistics to be significant-a danger that calls for some self-criticism. What are the deficiencies in the strategy I have just described?

In some cases, the statistical base may be dangerously thin. Among the eighteen booksellers in the sample, Constantin Lair of Blois ordered the smallest number of books-only 34 titles in all. He was a schoolmaster and small-time vintner, who sold books as a sideline, but his letters indicate that he depended on the STN for most of his supplies. Despite the modest size of his orders, I have therefore included him in the sample to illustrate the business of a marginal dealer in the capillary sector of the book trade. Veteran professional booksellers in large cities-Rigaud in Montpellier, for example, and Mossy in Marseilleplaced regular, carefully calculated orders with the STN, but they also drew supplies from other publisher-wholesalers such as the Société typographique de 
Lausanne and the Société typographique de Berne. Were the books furnished by the other typographical societies similar to those sold by the STN?

In order to form a general idea of the business of other Swiss houses, I have studied their correspondence with the STN. Some of their dossiers are enormous-631 letters from the Société typographique de Berne; 223 from the Société typographique de Lausanne in addition to 151 separate letters from its director, Jean-Pierre Heubach, and 83 from his associate, Jean-Pierre Bérenger; 421 from François Grasset of Lausanne; 207 from Barthélémy Chirol of Geneva; 130 from Jean Abram Nouffer of Geneva; and 75 letters from C. A. Serini of Basel. The constant flow of correspondence as well as exchanges among the publishers shows that they sold the same kind of books and many of the same titles. Their catalogues, which are included in the letters, are also essentially the same. Retailers like Rigaud and Mossy often ordered the same book from two or three of the Swiss houses in order to be sure of receiving an adequate supply on time and to spread out the risk of confiscation.

It would be incorrect, however, to claim that the STN archives are rich enough to represent the trade of all the publishing houses in Switzerland. They contain only three letters from the important Genevan publisher, Gabriel Cramer. 
Unlike the Neuchâtelois, he printed a great many original editions, especially of Voltaire's works. He never developed close contacts with the STN, because he resented its pirating, notably when it reprinted his edition of Voltaire's Questions sur l'Encyclopédie behind his back (and with the complicity of Voltaire). Similarly, the STN did not trade extensively with Barthélémy de Felice in nearby Yverdon, probably because he built his business around his expurgated and expanded edition of the Encyclopédie, which competed with the STN's speculation on the quarto reprint produced in Geneva, Neuchâtel and Lyon. The secondary literature on Swiss publishing contains a great deal of valuable information, but not enough to make systematic comparisons. ${ }^{18}$

It is therefore possible, although unlikely, that the business of other Swiss publishers differed substantially from that of the STN or that the Swiss trade as a whole had a different character from that of the Low Countries. But I have not found any indication of fundamental differences in studying the correspondence of Pierre Gosse Junior of The Hague (59 letters), J. L. Boubers of Brussels (35 letters), Clément Plomteux of Liège (15 letters), and other publishers to the north of France. When the directors of the STN made business trips through the Low Countries, they got a cool reception from most of the publishers they visited, because they were treated as rivals in the general struggle to sell the same kind of 
books. The prevalence of piracy everywhere around France's borders meant that dozens of publisher-wholesalers competed to satisfy the demand on the same French markets. The flow of pirated works that reached France from The Netherlands via Rouen was probably very similar to the current that passed from Switzerland through Lyon.

I must hedge that assertion with a "probably," because I have no solid proof. But to support it, I would insist on another key characteristic that distinguished early modern publishing from publishing today. Today's best-sellers are produced by one publisher who sells many copies of the same work, usually by reprinting several large editions, sometimes by selling off the paperback rights. In the eighteenth century, best-sellers were produced by many publishers in many small editions (usually about 1,000 copies) and sold on the same markets at the same time. That is why libraries now contain so many different versions of the same eighteenth-century works.

I have therefore concluded that my statistics provide an accurate measure of the STN's trade in France, even though they represent only a sample of all the orders that it received. They cover 1,145 titles-that is, books ordered by the 18 French booksellers between 1769 and 1789. Can the sample serve as an 
indication of the French trade in general? It is difficult to estimate the number of new works produced each year in France; but if one relies on the record of requests both for privileges and for tacit permissions, the total number of titles for the forty years from 1750 to 1789 comes to about 30,000 . The annual output of new books, which did not vary greatly after 1767 , came to about $750 .^{19}$ Therefore, one could estimate that the 1,145 titles in the sample were the equivalent of about eight per cent of the new legal works that appeared in France during the twenty years of the STN's existence. But the disparity of the sourcesorders by booksellers on the one hand and requests for permissions to publish on the other-vitiates any attempt to calculate exact percentages and proportions. I think it preferable to rely on calculations made by the book professionals as they went about their business. In deciding which books to reprint, the STN judged what would sell best on the market as a whole; and in ordering books from the STN, the booksellers indicated what they thought would sell best in their local territory. The numbers attached to the 1,145 titles in the statistical tables are not meant to be precise, but they are not random. They represent the judgment of experts who made it their business to satisfy demand as well as it could be perceived in the conditions of the eighteenth century. 
The statistics show the demand for each of the 1,145 works, and they provide a rough profile of the trade of each of the 18 booksellers. By aggregating them, it is possible to establish what may be called, if the anachronism be permitted, "best-seller" lists-that is, an indication of the books that were most in demand in the business of each bookseller and among all of them taken together. Of course, best-seller lists are often flawed today, owing to difficulties and deficiencies in sampling orders; and one should not expect a great deal of precision in lists of books that circulated two and a half centuries ago. I can claim only that the lists and tables I have compiled provide the best available guide to the preferences among the French for the literature that was available to them in book shops between 1769 and 1789 .

But before offering an overview of the statistics, it is important to take account of three additional difficulties. First, the uneven success in the STN's business during those twenty years means that the volume of orders it received was not consistent. It did not develop an extensive trade in France until 1771. In June 1783, the French state took effective measures to stanch the flow of illegal and pirated works from abroad. By the end of 1783 , the STN ran into serious financial difficulties and had to cut back on its activities, selling off its accumulated stock rather than expanding its business with numerous new 
publications and exchanges. Therefore, the most revealing statistics come from the period 1771-1784. Those covering the last five years of the ancien régime are less reliable.

Secondly, some titles weigh more heavily than others in the statistics based on the orders that the STN received. As mentioned, booksellers often ordered what their customers had requested, and they also followed their own instinct about what would sell, particularly when they learned of new publications from their commercial correspondence and from advertisements in periodicals. But in placing orders, they commonly chose from the works that appeared in the STN's catalogues, which it sent out frequently to booksellers everywhere in France. A title from the STN catalogue tended to attract more orders than a title that did not appear in it, just as the STN's own publications outweighed its livres d'assortiment in the pattern of its trade. An analysis of the statistics should take account of such factors, and it also may run into difficulties in interpreting the geographical distribution of the orders. If a bookseller in Marseille asked for nearly the same books as one in Besançon, did the similarity derive from the common character of the sources they consulted when they sent in their ordersnot only the STN's catalogues but also the prospectuses and circular letters that it sent through the mail and "annonces" that other publishers placed in literary 
reviews - or did the relatively wealthy and educated elite who bought books have the same preferences in both cities, perhaps even everywhere in France? I don't know, but I am struck by the lack of a local flavor in most of the orders. One must allow for special cases, such as the high demand for Protestant books in Nîmes, for medical treatises in Montpellier, and for works on viticulture in Bordeaux. But it could be that the same tastes, at least in the realm of contemporary literature, prevailed everywhere in the upper ranks of society, despite the great diversity in regional cultures.

Finally, I should point out that the statistics express a few characteristics that were peculiar to the trade of the STN. Although it did not specialize in any particular genre, it dealt heavily in Protestant works, and it drew on networks of Huguenots to market them in France, especially in cities like Nîmes and La Rochelle. It did not include many Catholic books in its stock, although at one point it offered to print a breviary for the Cistercians in Cîteaux. Therefore, the statistics give a rich picture of the demand for religious books among French Protestants, but not for religious literature in general. The STN did not carry some other kinds of literature-chapbooks, professional manuals, and most varieties of textbooks. It did, however, sell a great many works aimed at children, and it developed something of a specialty in travel literature. Highly forbidden books, 
such as pornographic novels and political libels, made up a fairly important portion of its business. But it did not specialize in them. In response to the demand from booksellers, it procured them by arranging exchanges with marginal publishers like Jacques-Benjamin Téron and Gabriel Grasset of Geneva, who speculated in the most dangerous (and usually the most profitable) sector of the trade. Despite some of its own publications, such as d'Holbach's Système de la

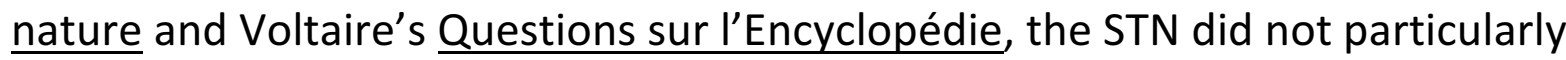
favor works of the Enlightenment philosophers. It carried a large assortment of ordinary books - "mid-list" works, as they are known today-and it invested heavily in best-sellers, or whatever it thought would sell best.

Did the judgment of its directors express any personal bias, either of taste or ideology, when they chose what to print and what to exchange? They had opinions of their own, of course, but nothing indicates that their principles, values, and attitudes differed substantially from those of their contemporaries. After reading thousands of their letters and studying their own publications (two of the founding partners of the STN, Frédéric-Samuel Ostervald and his son-inlaw, Jean-Elie Bertrand, did not merely publish books; they also wrote them), one gets the impression that they were cultivated, enlightened, and rather conservative gentlemen, fairly typical of the elite in the Swiss principality of 
Neuchâtel and Valangin, which had governed itself under Prussian suzerainty since 1707. Ostervald, the principal partner, was 56 in 1769. As a member of a distinguished family, he had held important positions in the city government, where he defended the interests of the bourgeoisie, and he had published a treatise on geography, which confirmed his position as one of the town's leading men of letters. Bertrand was a learned professor in the local collège and a pastor, until his exclusion from the Vénérable Classe des Pasteurs in 1771, when the STN published a clandestine edition of d'Holbach's atheistic Système de la nature. (It also published two refutations of the Système.) A volume of his sermons suggests that Bertrand subscribed to a conventional version of Christian morality, one far removed from the materialism of d'Holbach. Samuel Fauche, the third partner of the STN, left the company in 1772 after a quarrel over a libelous pamphlet that he had secretly slipped into an STN shipment in order to market it on his own, and he then resumed his trade as an independent bookseller. He was replaced in 1777 by Abram Bosset de Luze, a wealthy businessman with literary interests. Everything one knows about them suggests that the men who directed the STN held views that corresponded in a general way to enlightened ideas but that they did not use their business to promote the Enlightenment or any other cause. 
Their primary goal was to make money, "the moving force of everything" ("le grand mobile de tout"), as they put it in their correspondence. ${ }^{20}$

They did not always succeed. In fact, their near bankruptcy in 1783 could be taken as evidence that they had a poor record in linking supply with demand. But their financial difficulties resulted from other factors, notably the measure adopted by the French government on June 12, 1783 to restrict imports of all books by requiring them to travel via Paris, where they could be carefully inspected, before being shipped to their final destination. Therefore, even when it failed to fill them, the orders that the STN received from its customers constitute the best source for discovering what the demand for French literature actually was on the eve of the Revolution. The best available source. By pointing out its deficiencies, I do not mean to discourage the study of the statistics. On the contrary, I want to make them available for others to analyze and criticize. There is, after all, a great deal at stake in this kind of research, not only for the understanding of prerevolutionary France but also for the study of literature and of history in general.

This discussion of the conceptual and methodological problems is meant to clear the way for a presentation of the statistics and of the website itself. After 
downloading it, readers will see a map showing the location of the eighteen booksellers along the route followed by Favarger in 1778 . They can click on any location and work through several levels of information, which are organized in the same order for each of the booksellers.

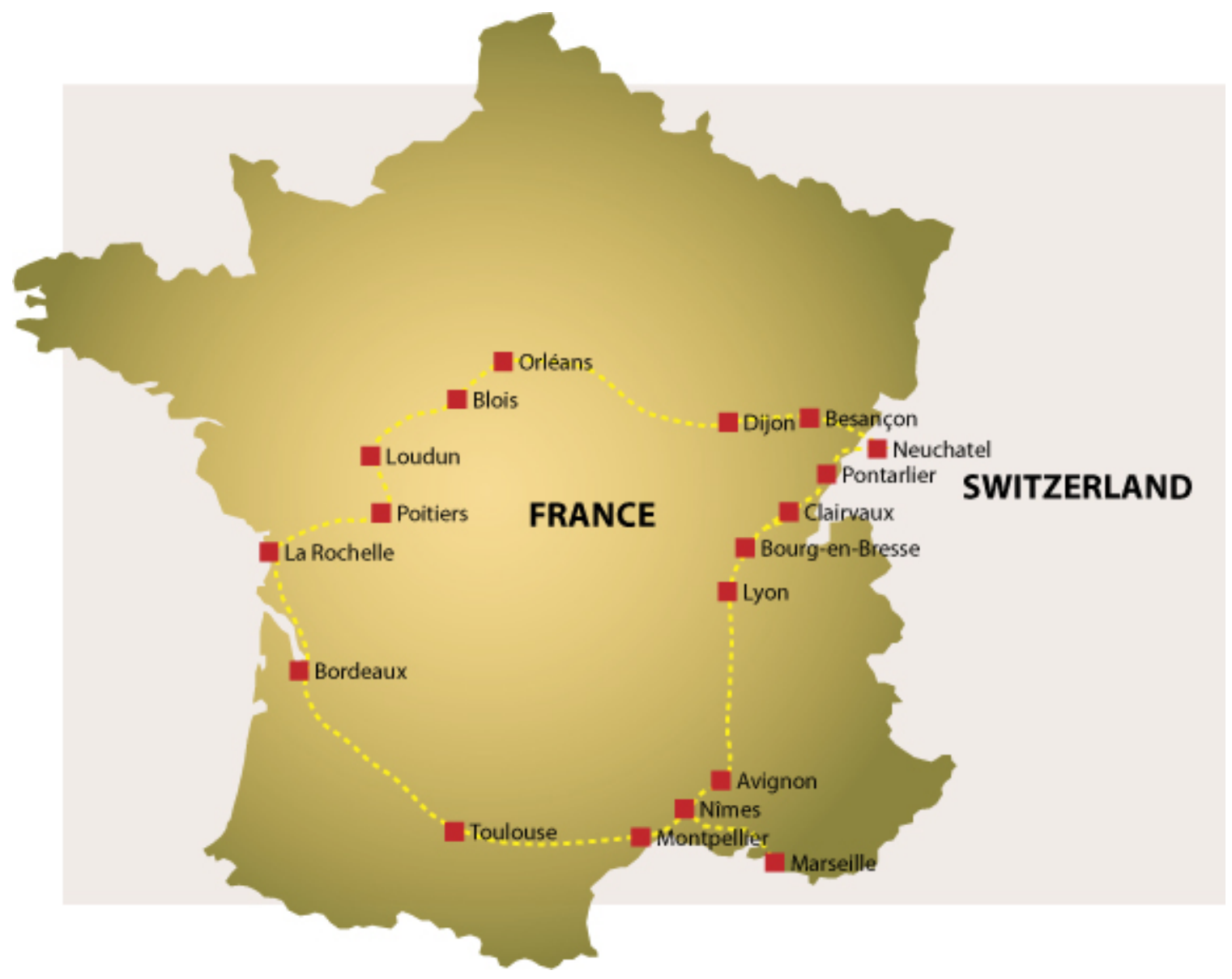

For example, they can click on Besançon, where they will see an eighteenth-century engraving of the city followed by the following: 
1. A summary of data about the economic, political, social, and cultural characteristics of the city.

2. A brief description of the trade of Jean-Félix Charmet, one of the most important booksellers in Besançon.

3. A monograph on Charmet and his business.

4. The transcription of the 179 letters Charmet sent to the STN.

5. A list of all the books he ordered, arranged alphabetically by title, with the number of copies and the date of each order for that title.

6. A list of the best-sellers in Charmet's trade

7. A digitized version of the manuscripts of Charmet's letters

8. An extensive compendium of information about other booksellers in Besançon, literacy, education, cultural institutions, commerce, administration, and other relevant topics.

Readers can also study Favarger's diary and his correspondence with the STN by clicking on the appropriate entries in the menu bar. If an item interests them-a particular book, author, publisher, bookseller, smuggler, or city-they can follow it through a series of links that connect all the documents in the data base. In this way, they can find their own path through the material and incorporate whatever they like in their own collections of data. Most readers 
probably will want to consult the master list, which contains all 1,145 titles and all the orders for them along with the dates and the number of copies requested in each order. The repetition of the orders provides a good index to the consistency of the demand for each book.

A best-seller list shows the books that were most in demand-and also those that actually reached readers, because, as explained, supply matched demand quite closely in the STN's dealings with the eighteen booksellers. In fact, the website contains two best-seller lists. The first includes works published by the STN and by the STN in cooperation with the Société typographique de Lausanne and the Société typographique de Berne. They weigh more heavily in the statistics than the books that came from the STN's general stock, which it built up by means of exchanges. (Of course, demand was the main consideration of the STN and its allies when they decided to reprint a book; that is why the first list is included on the website.) The second list, which contains only the books from the general stock - that is, the "livres d'assortiment" that the STN sold in its role as a wholesaler-gives a better-focused picture of demand in general. It favors Protestant works, which represent a specialty of the STN rather than the demand of French readers as a whole, and it might over-represent books intended for children; but otherwise it shows what kinds of books sold best on the literary 
market place. It goes as follows (the number after each title represents the total number of copies from all of the orders in the sample and is therefore significant as an indication of the relative importance of the demand for the books, not as a measure of the total number of copies that actually existed):

Psaumes (Les) de David, 2036

Anecdotes sur Mme la comtesse du Barry by Mathieu-François Pidansat de Mairobert, 1001

An (L') deux mille quatre cent quarante: rêve s'il en fût jamais by Louis-Sébastien Mercier, 691

Mémoire donné au roi par M. N. en 1778 sur l’administration provinciale by Jacques Necker, 367

Mémoires de l'abbé Terray: contrôleur général: contenant sa vie, son administration, ses intrigues et sa chute by Jean-Baptiste-Louis Coquereau, 324

Journal historique de la révolution opérée dans la constitution de la monarchie française par M. de Maupeou by Mathieu-François Pidansat de Mairobert et Barthélémy-François-Joseph Mouffle d'Angerville, 294

Histoire philosophique et politique des établissemens et du commerce des Européens dans les deux Indes by Guillaume-Thomas-François Raynal, 236

Abrégé des principes de la grammaire françoise, par Monsieur Restaut by Pierre Restaut, 231

Lectures pour les enfants, ou Choix de petits contes également propres à les amuser et à leur 
faire aimer la vertu, a nonymous, 213

Apparat royal, ou nouveau dictionnaire françois et latin: enrichi des façons de parler les plus élégantes en l'une et en l'autre langues: recueilli des meilleurs auteurs, et mis dans un ordre très-facile et très-méthodique pour la composition du françois en latin by Laurent-Etienne Rondet, 203

Abrégé de l'histoire sainte, et du catéchisme, retouché \& augmenté pour l'usage des écoles de charité de Lausanne by Jean-Frédéric Ostervald, 200

Comédiens (Les) ou Le foyer, comédie en un acte et en prose by Louis-Sébastien Mercier or James Rutledge, 200

Pucelle (La) d'Orléans, poème héroï-comique, en dix-huit chants by François-Marie Arouet dit Voltaire, 200

Recueil de comédies et de quelques chansons gaillardes, anonymous, 196

Prières pour tous les jours de la semaine, et sur divers sujets by Bénédict Pictet, 182

Antiquité et perpétuité de la religion protestante by Jean-Baptiste Renoult, 168

Vie privée de Louis XV, ou Principaux évènements, particularités et anecdotes de son règne by Barthélémy-François-Joseph Mouffle d'Angerville, 154 
Paysan (Le) perverti ou les dangers de la ville: histoire récente by Nicolas-Edme Rétif de la Bretonne, 149

Homme (De 1'), de ses facultés intellectuelles, et de son éducation: ouvrage posthume d'Helvétius, Claude-Adrien Helvétius, 144

Sermons pour les fêtes de l'Eglise chrétienne, pour servir de suite aux Discours sur la morale Evangélique by Elie Bertrand 143

Lettre d'un théologien à l'auteur du dictionnaire des Trois siècles littéraires by Jean Antoine Nicolas de Caritat, marquis de Condorcet, 143

Nourriture (La) de l'âme, ou Recueil de prières pour tous les jours de la semaine pour les principales fêtes de l'année et sur différens sujets intéressans by Jean-Rodolphe Ostervald, 137

Collection complète des oeuvres de Jean-Jacques Rousseau by Jean-Jacques Rousseau, 136

Lettres philosophiques by François-Marie Arouet dit Voltaire, 130

Vrai (Le) communiant ou Traité de la Sainte Cène et des moyens d'y bien participer by Daniel de Superville, 130

Christianisme (Le) dévoilé, ou Examen des principes et des effets de la religion chrétienne by PaulHenri-Dietrich Thiry, baron d'Holbach, 128

Voyage sentimental, par M. Sterne sous le nom d'Yorick, traduit de l'anglois by Laurence Sterne, 127 
Amants (Les) républicains, ou Lettres de Nicias et Cynire by Jean-Pierre Bérenger, 127

Compère (Le) Mathieu ou les bigarrures de l'esprit humain by Henri-Joseph du Laurens, 124

Dictionnaire raisonné universel d'histoire naturelle by Jacques-Christophe Valmont de Bomare, 120

Avis au peuple sur sa santé by Samuel-Auguste-André-David Tissot, 119

An extensive commentary on this list lies beyond the bounds of this essay; but to summarize a complex body of evidence, I think it valid to describe literary demand on the eve of the Revolution as characterized by four types of works:

1. A corpus of scandalous literature, which conveyed a disabused and potentially seditious view of current events: for example, Anecdotes sur Mme la comtesse du Barry and Mémoires de l'abbé Terray.

2. Works imbued with the spirit of the Enlightenment, sometimes in a

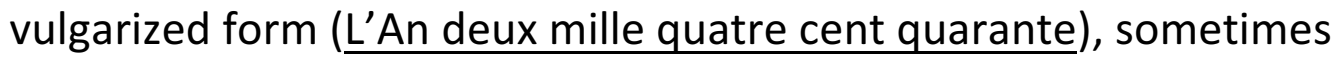
encyclopedic in scope (Raynal's Histoire philosophique), and often radical (Le Christianisme dévoilé by d'Holbach and De l'homme by Helvétius).

3. Educational and utilitarian books such as Pierre Restaut's Abrégé des principes de la grammaire, the Dictionnaire raisonné universel d'histoire 
$\underline{\text { naturelle by Valmont de Bomare, and Tissot's Avis au people sur sa }}$ santé.

4. Light fiction, often amusing and erotic: for example, Sterne's Voyage $\underline{\text { sentimental, Le Paysan perverti by Restif de la Bretonne, and Le }}$ Compère Mathieu by Henri-Joseph du Laurens.

The religious works that figure prominently on the list were written or edited by Protestants and intended for Protestant readers, but they may have reached some Catholics among French readers in general. If one consults the best-seller list that includes books published by the STN, one finds the same general pattern; but it also features books by the STN's favorite authors: LouisSébastien Mercier, Claude-Joseph Dorat, and S.-F. Ducrest de Saint Aubin, comtesse de Genlis. Add to their publications some history (especially the popular works by William Robertson and Claude-François-Xavier Millot) and travel books (the adventures of James Cook and Jean François de Galaup, comte de La Pérouse), and you have a good view of the literary preferences of the Frenchthat is, the works that were most in demand on the literary market and the works that they actually consumed, whatever consumption may mean in the realm of literature. 
Notes 
${ }^{1}$ Alexis de Tocqueville, The Old Regime and the French Revolution (Garden City, New York, 1955), Part Three, chapters 1-3.

${ }^{2}$ Daniel Mornet, “Les enseignements des bibliothèques privées (170-1780) ," Revue d'histoire littéraire de la France, 17 (1910), 449-492.

${ }^{3}$ For an account of the Revolution's origins that stresses cultural history and rejects Mornet's approach, see Roger Chartier, Les Origines culturelles de la Révolution française (Paris, 1990), especially pp. 9-31.

${ }^{4}$ For a survey of the literature and a discussion of the problems of measuring French book production before the nineteenth century, see my essay originally published as "Reading, Writing, and Publishing in Eighteenth-Century France: A Case Study in the Sociology of Literature," Daedalus (Winter, 1971), 214-256 and reprinted in The Literary Underground of the Old Regime (Cambridge, MA., 1982), 167-208. On the inadequacy of the registers of the Stationers' Company, see D. F. McKenzie, Making Meaning. "Printers of the Mind" and Other Essays (Amherst, 2002), chapters 4 and 5. On the unrepresentative aspects of the Frankfurt and Leipzig book fair catalogues, see Reinhard Wittmann, “Die frühen Buchhändlerzeitschriften als Spiegel des literarischen Lebens, $\underline{\text { Archiv für }}$ Geschichte des Buchwesens 13 (1973), 614-932 and Reinhard Wittman Geschichte des Deutschen Buchhandels (Munich, 1991), 111.

${ }^{5}$ I have developed this argument at length in Censors at Work. How States Shaped Literature (New York, 2014). See also the excellent study by Raymond Birn, Royal Censorship of Books in Eighteenth-Century France (Stanford, 2012).

${ }^{6}$ As an example of the economic concerns of the French administrators of the book trade, see Chrétien-Guillaume de Lamoignon de Malesherbes, Mémoires sur la librairie, ed. Roger Chartier (Paris, 1994; text composed in 1759), 85-86.

${ }^{7}$ See Wittmann, Geschichte des Deutschen Buchhandels, chapters 3 and 4 and Johann Adolf Goldfriedrich, Geschichte des deutschen buchhandels vom beginn der fremdherrschaft bis zur reform des Börsenvereins im neuen Deutschen Reiche (1805-1889 (Leipzig, 1886-1909), vol. 3. 
${ }^{8}$ I have developed this argument more fully in "The Science of Piracy: A Crucial Ingredient in Eighteenth-Century Publishing," Studies on Voltaire and the Eighteenth Century 12 (2003), 3-29.

${ }^{9}$ STN to Astori of Lugano, April 15, 1775 in the archives of the STN, Bibliothèque publique et universitaire de Neuchâtel, in Neuchâtel, Switzerland.

${ }^{10}$ Widow Charmet to STN, August 16, 1784, archives of the STN.

${ }^{11}$ I have published a detailed study of one such bookseller, Bruzard de Mauvelain: "Trade in the Taboo: The Life of a Clandestine Book Dealer in Prerevolutionary France, The Widening Circle. Essays on the Circulation of Literature in Eighteenth-Century Europe, ed. Paul J. Korshin (Philadelphia, 1976), 11-83.

${ }^{12}$ These criticisms apply especially to The French Book Trade in Enlightenment Europe, 1769-1794, ed. Simon Burrows (2012), online at http://fbtee.uws.edu.au

${ }^{13}$ See Giles Barber, "The Cramers of Geneva and their trade in Europe between 1755 and 1766," Studies on Voltaire and the Eighteenth Century, 30 (1964), pp. 377-413 and Georges Bonnant, "La librairie genevoise dans la péninsule ibérique au XVIIle siècle," Genava, 9 (1961), pp. 104-124.

${ }^{14}$ See Goldfriedrich, Geschichte des deutschen buchhandels, vol. 3 and Wittmann, Geschichte des deutschen buchhandels.

${ }^{15}$ See Jeffrey Freedman, Books Without Borders in Enlightenment Europe. French Cosmopolitanism and German Literary Markets (Philadelphia, 2012), chapter 1.

${ }^{16}$ See The Business of Enlightenment: A Publishing History of the Encyclopédie, 1775-1800 (Cambridge, Mass., 1979).

${ }^{17}$ For a detailed critique of this study, see my review essay,"The French Book Trade in Enlightenment Europe, 1769-1794," Reviews in History (December, 2012) at http://www.history.ac.uk/reviews/review/1355.

${ }^{18}$ This is not the place to include a bibliography of this large subject, but the reader can follow up the numerous references in two collective works: Cinq siècles d'imprimerie genevoise, eds. Jean-Daniel Candaux and Bernard Lescaze (Geneva, 1981) and Aspects du livre neuchâtelois, eds. Jacques Rychner and Michel Schlup (Neuchâtel,1986). 
${ }^{19}$ See François Furet, "La "librairie" du royaume de France au 18e siècle," in Livre et société dans la France du $\underline{\text { XVIIle siècle vol. I (Paris, 1965), pp. 7-14 and Robert Estivals, La Statistique bibliographique de la France sous la }}$ monarchie au XVIIle siècle (Paris, 1965), pp. 213-291. The estimate of 30,000 new titles for the 40 years before 1790 is probably high, because many requests for privilèges, permissions du Sceau (an authorization like a privilege but one that did not convey the exclusive right to sell a book), and permissions tacites did not result in actual publications. Also, many of the requests concerned proposals to reprint works whose privilèges had expired. There are no records for casual authorizations such as simples tolérances and permissions de police, but they mainly concern ephemera. Of course, all of the official records exclude illegal literature. The STN sold a great many books that would not have been submitted for any kind of authorization by state officials, but it pirated an even larger number of legal and quasi-legal works. It also sold works published earlier than when it began business, but it concentrated heavily in the trade in recent literature.

${ }^{20}$ Bosset to STN, April 1, 1780, in the dossier of Bosset de Luze, archives of the Société typographique de Neuchâtel. For biographical sketches of the STN's partners, see Biographies neuchâteloises, ed. Michel Schlup, vol. I (1996), pp. 197-201 and L’Edition neuchâteloise au siècle des Lumières. La Société typographique de Neuchâtel (1769-1789), eds. Robert Darnton, Jacques Rychner, and Michel Schlup (Neuchâtel, 2002), pp. 67-70. 